\title{
Impact of Cover Crops and Poultry Litter on Selected Soil Properties and Yield in Dryland Soybean Production
}

\author{
Sapana Pokhrel ${ }^{1}$, William L. Kingery ${ }^{1}$, Michael S. Cox ${ }^{1}$, Mark W. Shankle ${ }^{1,2}$ and Shankar G. Shanmugam ${ }^{1,3, *(D)}$ \\ 1 Department of Plant and Soil Sciences, Mississippi State University, Starkville, MS 39762, USA; \\ sp2189@msstate.edu (S.P.); wkingery@pss.msstate.edu (W.L.K.); MCox@pss.msstate.edu (M.S.C.); \\ mark.shankle@msstate.edu (M.W.S.) \\ 2 Pontotoc Ridge-Flatwoods Branch Experiment Station, North Mississippi Research and Extension Center, \\ 8320, Hwy 15 South, Pontotoc, MS 38863, USA \\ 3 Institute for Genomics, Biocomputing and Biotechnology, Mississippi State University, \\ Starkville, MS 39762, USA \\ * Correspondence: sg383@igbb.msstate.edu
}

Citation: Pokhrel, S.; Kingery, W.L.; Cox, M.S.; Shankle, M.W.;

Shanmugam, S.G. Impact of Cover

Crops and Poultry Litter on Selected Soil Properties and Yield in Dryland Soybean Production. Agronomy 2021, 11, 119. https://doi.org/10.3390/ agronomy11010119

Received: 30 November 2020

Accepted: 6 January 2021

Published: 9 January 2021

Publisher's Note: MDPI stays neutral with regard to jurisdictional clai$\mathrm{ms}$ in published maps and institutional affiliations.

Copyright: (C) 2021 by the authors. Licensee MDPI, Basel, Switzerland. This article is an open access article distributed under the terms and conditions of the Creative Commons Attribution (CC BY) license (https:// creativecommons.org/licenses/by/ $4.0 /)$.

\begin{abstract}
Soil biological properties are important for the stabilization and preservation of a good soil structure. Management practices can affect the diversity and population of microorganisms, which could beneficially change soil properties and promote a more sustainable dryland crop production. This study was established near Pontotoc, MS, USA $\left(34^{\circ} 07^{\prime} \mathrm{N}, 88^{\circ} 59^{\prime} \mathrm{W}\right)$ on an Atwood silt loam (fine-silty, mixed, semiactive, thermic Typic Paleudalf) to evaluate the impacts of cover crops, planting dates and fertilizer sources (poultry litter, inorganic fertilizer and no fertilizer) on selected biologically related soil properties in a no-tillage, dryland soybean production. Soil analyses included total carbon and nitrogen, permanganate oxidizable carbon (POXC), easily extractable glomalin-related soil protein (EE-GRSP), water stable aggregate (WSA) and soil pH. Cover crop production and soybean yield were also determined. The results indicated that the fertilizer source had an impact on total nitrogen, EE-GRSP and soybean yield. Total $\mathrm{N}$ was $6 \%$ higher with poultry litter at the early planting date compared to no fertilizer (control) $(p<0.0018)$ and at the late planting date, when total $\mathrm{N}$ and EE-GRSP were increased by $11 \%$ and $13 \%$, respectively, with poultry litter compared to no fertilizer. Additionally, soil pH was reduced by 0.25 units in the poultry litteramended treatment. Soybean yield was increased by $68 \%$ and $51 \%$ in early-planted soybean and $42 \%$ and $40 \%$ in late-planted soybean with poultry litter and inorganic fertilizer, respectively, compared to no fertilizer. This study revealed that biological soil properties and soybean yield were influenced by poultry litter application. The results showed no significant effects of cover crops over the short time period of the study.
\end{abstract}

Keywords: soil microorganisms; cover crop; poultry litter; glomalin; dryland

\section{Introduction}

The adaptation of management practices is a priority for sustainable crop production in a dryland system with poor soil quality. Low soybean yield in dryland systems can be directly related to a lack of moisture in critical plant development stages during the growing season [1]. More than half of Mississippi state soybean hectares are produced under a dryland system and productivity is typically low if timely rainfall events do not occur [2]. Soil moisture is an important determinant of crop yield in a dryland cropping system [3]. Soil structure influences moisture status in the root zone and soil microorganisms are important for the stabilization and preservation of a good soil structure. In some North Mississippi fields, wells are drilled as deep as $200 \mathrm{~m} \mathrm{[4]} \mathrm{At} \mathrm{this} \mathrm{depth,} \mathrm{irrigation} \mathrm{is}$ not economically feasible. Farmers need an irrigation alternative that can increase yield with low cost. Thus, research is needed to determine management practices for a more sustainable dryland soybean production system. 
The use of cover crops and poultry litter as a management practice has been adopted in many no-tillage systems. No-tillage maintains soil moisture status by influencing evaporation, drainage and runoff after rainfall events $[5,6]$. The inclusion of cover crops in a no-tillage production system enhances soil physical properties and microbial enzymatic activities $[7,8]$. Cover crops have multifunctional properties that enhance soil C, soil porosity, water-stable aggregates (WSA) and soil organic matter [9-11]. Residue from the above-ground cover crop production increases soil organic matter, while below-ground root exudates diversify the energy sources available to soil microbes that improve soil properties [12], which in turn benefit microbial communities [13-15]. Improved activities include enhanced nutrient cycling, better soil quality and ultimately increased cash crop yield [16]. The inclusion of legumes as a cover crop can also fix atmospheric N, which can reduce the rate of applied $\mathrm{N}$ fertilizer required by the cash crop [16]. In the US, the use of winter cover crops in the farm management system has increased by about two million ha (5 million ac) between 2012 and 2017 [17]. The optimum application of inorganic fertilizer and organic fertilizer such as poultry litter remarkably improves the soil health, which is defined as the vital functional capacity of soil for the sustainable development of plants, animals and humans [18]. Cover crop termination dates and methods depend on the aim of their integration into a cropping system. Two weeks of delay in the termination of cereal rye and hairy vetch increased biomass accumulation by $39 \%$ and $61 \%$, respectively and growing cover crops until three weeks before planting the cash crop increased mycorrhizal fungi population $[19,20]$. Lawson et al. [21] observed a 60\% increase in cover crop biomass with a month delay in termination on a Briscot loam (coarse-loamy, mixed, superactive, nonacid, mesic Fluvaquentic endoaquept) in Washington.

Field studies have demonstrated profitable results of cover crop integration on the enhancement of soil properties, ultimately increasing the cash crop yield. A 15 year study in Kansas noted an improvement in aggregate stability and organic $C$ on a Geary silt loam (fine-silty, mixed, superactive, mesic Udic Argiustoll) over time [9]. However, there may not be a short-term effect (2-5 years) of cover crops on soil total organic $C$ because it responds slowly to changes in management practices. Therefore, labile $\mathrm{C}$ may be used as a short-term indicator of management practices [22,23]. Research also indicates that fertilizer treatments based on soil test results increase soybean yield in dryland soybean systems [24]. The results of Ren et al. [25] showed that inorganic fertilizer increases soil labile C but there was no change in total $\mathrm{C}$ and total $\mathrm{N}$ content on a silt loam soil in a six-year study. Geisseler and Scow [26] found that inorganic fertilizer increases organic C by $12.8 \%$ and microbial biomass $C$ by $15.1 \%$ in a review of studies with at least a five-year observation period. The application of poultry litter increases total $\mathrm{C}, \mathrm{N}$, soil $\mathrm{pH}$ and $\mathrm{N}$ mineralization in comparison to inorganic fertilizer [27]. Poultry litter improves soil properties, plant nutrient availability and plant development, ultimately leading to an increase in crop yield [28-31]. It also increases beneficial fungal and bacterial populations such as arbuscular mycorrhizal fungi (AMF) and nitrifying bacteria and suppresses pathogens such as M. incognita [32] Mierzwa-Hersztek et al. [33] reported that nitrifying bacteria activities increased 50\% with the addition of poultry litter in a two-year study on loamy sand soil, which might be the result of higher $\mathrm{C}$ substrate. Poultry litter contains organic $\mathrm{N}$, which serves as a slowrelease fertilizer and it can help fulfill the soybean $\mathrm{N}$ requirement during peak stages of development [34,35].

Soil health, the capacity of soil to function as a living system and support the development of plant and animals, can be improved with changes in management practices. These changes are measured as water-stable aggregates (WSA), permanganate oxidizable $\mathrm{C}$ (POXC) and microbial respiration [36,37]. A 15 year study in the Californian San Joaquin Valley showed an improvement of soil properties with the use of cover crops in a no-tillage cash cropping system [38]. This study noted an improvement in the water infiltration rate, WSA, total $\mathrm{C}$ and total $\mathrm{N}$ in the upper $15 \mathrm{~cm}$ of soil compared to a no-cover-crop standard tillage system. Aldridge et al. [33] and Amado et al. [33] demonstrated a higher C content in surface soil with cover crops in no-tillage treatments compared to fallow treatment. 
Permanganate oxidizable $\mathrm{C}$ is composed of soil microbial biomass, fresh organic material, particulate organic matter and root exudates that have a relatively short mineralization time (2-5 years). The determination of permanganate oxidizable $C$ is an economical and fast method to quantify biologically active labile $C$ in soil, which can be used to indicate a change produced by a management practice $[37,39]$. The rapid response of POXC to changes in soil health due to management practices may help farmers to develop a new strategy to increase soil health.

Easily extractable- glomalin-related soil protein (GRSP) is a labile fraction of GRSP and is believed to be a recently produced glomalin; it mainly contains glycoprotein, which is produced by arbuscular mycorrhizal fungi (AMF) [40,41]. The soil protein EE-GRSP is also a part of the C-based soil component that performs as an adhesive material which may enhance aggregation and stimulate plant growth [42-46]. Thermostable EE-GRSP also helps in enhancing drought tolerance in plants [47]. Studies reveal that management practices influence AMF and GRSP production in soil by influencing the root exudates and microbial population $[44,48,49]$. Cover crops have been shown to improve the AMF population in cash crops, which indirectly affects GRSP production and WSA formation [50]. Zhang et al. [51] reported improved fungal energy sources and habitats and enhanced hyphae development for glomalin production on a Cambisol with poultry litter.

Therefore, cover crop and fertilizer use as part of a farming system may improve soil properties. Cover crops may improve aggregate stability with the exudation of polysaccharides, root mucilage and the root system itself [52]. The addition of poultry litter increases the $C$ content of the soil, which may improve macroaggregates. A study by Zhang et al. [51] noted that glomalin, microbial biomass $C$ and organic $C$ in soil were highly influenced by poultry litter in a Cambisol soil in China.

Many studies have shown that these management practices change soil properties including soil organic matter, soil aggregate stability, soil organic $C$, total $C$, total nitrogen (N), soil pH and glomalin [22,53-55]. In contrast, some studies have shown no effect of cover crops on soil properties. For example, a two-year study on a five-year crop rotation field showed no differences regarding aggregate stability and organic $C$ due to cover crop and cattle manure application in a Albic Stagic Luvisol in the Estonian area of northern Europe [56]. Long-term studies in various physiographic regions of North Carolina showed no impact of cover crops on soil aggregation. The same study showed differences regarding biological properties but these were inconsistent [57]. The discrepancy in research results warrants further investigation. Limited research has been conducted with a dryland soybean production system that has elucidated the need for the combined impact of notillage, cover crop and fertilizer sources on biologically related soil properties. In addition, the impact of these applications may vary among different site factors; thus, the impacts cannot be generalized to other regions with different conditions.

The purpose of this project was to evaluate the combined effects of cover crop and fertilizer source in no-tillage conditions on dryland soybean production with the overarching goal of determining ways to help producers improve soil health and increase soybean yield. The soil health indicators of total $\mathrm{C}$, total N, permanganate oxidizable carbon (POXC), easily extractable glomalin-related soil protein (EE-GRSP), WSA and soil pH were determined to measure the short-term effects of management practices on biologically related soil characteristics. We hypothesized that the combination of cover crop and fertilizer source will beneficially change soil biological properties in a no-till, dryland soybean system. Moreover, the cover crop production and soybean yield would increase with cover crop and fertilizer treatment over time. The objective of this study was to determine the effects of cover crops, inorganic fertilizer and poultry litter on biologically related soil properties in a no-tillage, dryland soybean system. 


\section{Materials and Methods}

\subsection{Study Site}

A cover crop study was conducted at the Pontotoc Ridge-Flatwoods Branch Experiment Station in Pontotoc County, MS, USA $\left(34^{\circ} 07^{\prime} \mathrm{N}, 88^{\circ} 59^{\prime} \mathrm{W}\right)$. The study was initiated in October 2017 and continued until September 2020. The soil series at the study site was an Atwood silt loam (fine-silty, mixed, semi-active, thermic Typic Paleudalf) with 13.9\% clay, $17.6 \%$ sand and $68.5 \%$ silt (measured by pipette-method) on a 3\% slope (Soil Survey, Natural Resources Conservation Service (NRCS)). The study was conducted under no-tillage, rainfed conditions. Prior to this experiment, corn and soybean were planted in 2016 and 2017, respectively. An initial soil test determined a $\mathrm{pH}$ of 6.67 and 1.57\% organic matter. The monthly mean maximum and minimum air temperature, total monthly rainfall for the study period and 30 year mean (1981-2010) at the experiment station were taken from reports by the National Oceanic and Atmospheric Administration [58] (Tables 1 and 2).

Table 1. Monthly mean maximum, minimum temperatures $\left({ }^{\circ} \mathrm{C}\right)$ and rainfall for the first, second and third year of study and 30 year mean monthly normal temperature at Pontotoc, MS.

\begin{tabular}{|c|c|c|c|c|c|c|c|c|c|c|c|c|}
\hline \multicolumn{5}{|c|}{ Maximum Temperature $\left({ }^{\circ} \mathrm{C}\right)$} & \multicolumn{4}{|c|}{ Minimum Temperature $\left({ }^{\circ} \mathrm{C}\right)$} & \multicolumn{4}{|c|}{ Monthly Total Rainfall (mm) } \\
\hline Month & Year 1 & Year 2 & Year 3 & Mean & Year 1 & Year 2 & Year 3 & Mean & Year 1 & Year 2 & Year 3 & Mean \\
\hline October & 24.6 & 22.9 & 35.6 & 22.9 & 9.5 & 10.3 & 3.9 & 10.1 & 46 & 41 & 165 & 109 \\
\hline November & 21.4 & 15.1 & 23.3 & 16.9 & 7.2 & 4.0 & -10.0 & 5.2 & 37 & 150 & 99 & 120 \\
\hline December & 14.6 & 11.2 & 21.1 & 11.2 & 1.1 & -0.6 & -4.4 & 0.6 & 158 & 96 & 226 & 164 \\
\hline January & 9.0 & 14.5 & 20.6 & 9.9 & -5.4 & -1.1 & -5.6 & -0.9 & 166 & 189 & 189 & 118 \\
\hline February & 16.3 & 15.5 & 21.7 & 12.4 & 4.7 & 2.0 & -2.8 & 1.1 & 334 & 348 & 281 & 134 \\
\hline March & 19.2 & 17.1 & 30.0 & 17.3 & 3.6 & -1.5 & -2.8 & 5.2 & 76 & 86 & 208 & 127 \\
\hline April & 20.9 & 23.5 & 27.2 & 21.9 & 5.1 & 9.3 & 3.3 & 9.6 & 209 & 240 & 146 & 137 \\
\hline May & 29.8 & 29.2 & 30.6 & 26.3 & 16.7 & 15.7 & 11.1 & 14.9 & 120 & 151 & 125 & 146 \\
\hline June & 31.4 & 30.2 & 32.2 & 29.9 & 19.6 & 17.8 & 13.9 & 19.1 & 176 & 191 & 205 & 123 \\
\hline July & 32.6 & 32.1 & 34.4 & 31.8 & 21.3 & 20.2 & 19.4 & 20.8 & 32 & 153 & 186 & 110 \\
\hline August & 32.2 & 32.4 & 35.6 & 31.8 & 20.4 & 21.1 & 17.2 & 20.2 & 100 & 87 & 121 & 102 \\
\hline September & 30.5 & 34.3 & 32.2 & 28.7 & 19.5 & 18.6 & 9.4 & 16.3 & 161 & 3 & 50 & 93 \\
\hline
\end{tabular}

Year 1 = October 2017-September 2018; Year 2 = October 2018-September 2019; Year 3 = October 2019-September 2020; Mean = 30 years (1981-2010). 
Table 2. Cover crop and soybean operation, fertilizer application and soil sampling dates from early and late planting dates in Pontotoc, MS.

\begin{tabular}{ccccccccc}
\hline & Cover Crop & & \multicolumn{2}{c}{ Fertilizer Source } & \multicolumn{2}{c}{ Soybean Operation } & Soil \\
\hline Planting & $\begin{array}{c}\text { Biomass } \\
\text { Collection }\end{array}$ & Killing & $\begin{array}{c}\text { Poultry } \\
\text { Litter }\end{array}$ & $\begin{array}{c}\text { Inorganic } \\
\text { Fertilizer }\end{array}$ & Planting & Cultivar & Harvest \\
Sampling
\end{tabular}

\subsection{Experimental Design}

The experimental design was a randomized complete block design with a split-plot treatment structure of two factors and three replications. The main plot factor was cover crops and fertilizer source was the sub-plot factor. There were two soybean planting dates (i.e., early and late planting date/ early and late-terminated cover crop) which were studied separately. Each planting date consisted of 15 whole plots of $167.2 \mathrm{~m}^{2}\left(1800 \mathrm{ft}^{2}\right)$ each and 45 sub-plots $\left(74.4 \mathrm{~m}^{2}\right.$ each $\left(800 \mathrm{ft}^{2}\right)$ for each soybean planting date. The five cover crop treatments included cereal rye (Secale cereale), vetch (Vicia villosa), wheat (Triticum aestivum), mustard (Brassica rapa) and cereal rye (CC-mix) and native vegetation (allowing naturally seeded weeds to grow-control). The three fertilizer treatments were poultry litter, inorganic fertilizer (phosphorus, potassium and sulfur) and no-fertilizer control.

\subsection{Field Methods}

Cover crops were drill-seeded at the rate of $91.91 \mathrm{~kg} \mathrm{ha}^{-1}$ of cereal rye, $22.42 \mathrm{~kg} \mathrm{ha}^{-1}$ of vetch, $94.15 \mathrm{~kg} \mathrm{ha}^{-1}$ of wheat, $71.73 \mathrm{~kg} \mathrm{ha}^{-1}$ of cereal rye and $16.81 \mathrm{~kg} \mathrm{ha}^{-1}$ of the mustard mixture in both years. Cover crops were killed with $N, N^{\prime}$-dimethyl-4,4'-bipyridinium dichloride (paraquat), $\mathrm{N}$-(phosphonomethyl) glycine (glyphosate) and 3,6-dichloro-2methoxybenzoic acid (dicamba) in 2018, 2019 and 2020, respectively Herbicides were applied twice at an interval of about 10 days before planting herbicide-resistant soybean. Poultry litter application was based on an equivalent amount of $\mathrm{P}_{2} \mathrm{O}_{5}$ as inorganic fertilizer. The poultry litter analysis was conducted by the nutrient analysis laboratory United States Department of Agriculture- Agricultural Research Service (USDA-ARS) Mississippi, USA. Based on the soil test, potassium $(\mathrm{K})$, phosphorus $(\mathrm{P})$ and sulfur $(\mathrm{S})$ were recommended for the production of $2690 \mathrm{~kg} \mathrm{ha}^{-1}$ of soybean in this soil. The recommended inorganic fertilizer rates were $\mathrm{P}_{2} \mathrm{O}_{5}$ at $134.5 \mathrm{~kg} \mathrm{ha}^{-1}, \mathrm{~K}_{2} \mathrm{O}$ at $33.63 \mathrm{~kg} \mathrm{ha}^{-1}$ and $\mathrm{S}$ at $22.42 \mathrm{~kg} \mathrm{ha}^{-1}$ based on Lancaster macronutrient extraction method soil test recommendation from Southern Soil Labs (Yazoo City, MS, USA). Phosphorus was applied as triple superphosphate at $292.5 \mathrm{~kg} \mathrm{ha}^{-1}$. Potassium was applied at $56.04 \mathrm{~kg} \mathrm{ha}^{-1}$ as muriate of potash. Sulfur was applied as $90 \%$ elemental $\mathrm{S}$ at $24.7 \mathrm{~kg} \mathrm{ha}^{-1}$. Poultry litter was surface-broadcasted at $4695.3 \mathrm{~kg} \mathrm{ha}^{-1}$ in 2018, 4483.4 $\mathrm{kg} \mathrm{ha}^{-1}$ in 2019 and a similar amount in 2020. Each plot was treated with the same treatment each year. Soybean was planted with a no-till planter at 
316,160 seeds per ha ${ }^{-1}$. Each sub-plot had eight rows of soybean. All the field operations are listed in Tables 3 and 4.

Table 3. Chemical composition of poultry litter applied to the soybean plots at Pontotoc RidgeFlatwoods Branch Experiment Station, Pontotoc, MS, USA. TN: total nitrogen; TC: total carbon.

\begin{tabular}{|c|c|c|c|c|c|c|c|c|c|}
\hline Year & Moisture \% & $\mathrm{TN}\left(\mathrm{g} \mathrm{kg}^{-1}\right)$ & $\mathrm{TC}\left(\mathrm{g} \mathrm{kg}^{-1}\right)$ & $\mathbf{K}$ & $\mathbf{P}$ & $\mathrm{Cu}$ & Zn & $\mathrm{Fe}$ & Mn \\
\hline & & & & $\mathrm{kg}^{-}$ & & & $\mathrm{kg}^{-1}$ & - $-\mathrm{mg}$ & \\
\hline 2018 & 24.1 & 31 & 250 & 25.7 & 13.0 & 0.400 & 0.424 & 1.617 & 0.656 \\
\hline 2019 & 25.9 & 32 & 229 & 28.8 & 17.5 & 0.113 & 0.416 & 0.859 & 0.455 \\
\hline
\end{tabular}

Table 4. Main effects of cover crop on cover crop production in 2018, 2019 and 2020 and average soybean yield in early and late-terminated cover crops.

\begin{tabular}{cccc}
\hline \multicolumn{4}{c}{ Cover Crop Production (kg ha-1) } \\
\hline Cover Crop & $\mathbf{2 0 1 8}$ & $\mathbf{2 0 1 9}$ & $\mathbf{2 0 2 0}$ \\
\hline Early-terminated cover crop & $1645^{1}(200)^{2} \mathrm{a}$ & $3639(326) \mathrm{a}$ & $1986(288) \mathrm{a}$ \\
Cereal rye & $1768(288) \mathrm{a}$ & $3035(442) \mathrm{a}$ & $2037(316) \mathrm{a}$ \\
CC-mix & $418(138) \mathrm{b}$ & $3140(690) \mathrm{a}$ & $1228(174) \mathrm{b}$ \\
Native veg. & $685(16) \mathrm{b}$ & $1953(260) \mathrm{a}$ & $1313(142) \mathrm{b}$ \\
Vetch & $1770(108) \mathrm{a}$ & $3532(379) \mathrm{a}$ & $2026(207) \mathrm{a}$ \\
Wheat & 0.0014 & 0.2108 & 0.0244 \\
$p$ value & $4425(292) \mathrm{a}$ & $4228(478) \mathrm{a}$ & $3467(468) \mathrm{ab}$ \\
Late-terminated cover crop & $4408(330) \mathrm{a}$ & $4008(457) \mathrm{a}$ \\
Cereal rye & $4284(368) \mathrm{a}$ & $2632(350) \mathrm{a}$ & $2544(346) \mathrm{bc}$ \\
CC-mix & $2254(52) \mathrm{b}$ & $3545(383) \mathrm{a}$ & $2473(330) \mathrm{c}$ \\
Native veg. & $1546(212) \mathrm{b}$ & $2989(664) \mathrm{a}$ & $3244(294) \mathrm{abc}$ \\
Vetch & $4386(363) \mathrm{a}$ & 0.3641 & 0.0031 \\
Wheat & $<0.0001$ & &
\end{tabular}

\footnotetext{
${ }^{1}$ Means followed by different letters in columns are significantly different at the 0.05 level using Fisher's protected least significant difference (LSD) test and variables with no letters in columns are not significantly different; Native Veg = Native vegetation, CC-mix = cereal rye and mustard;

${ }^{2}$ Standard error in parenthesis.
}

\subsection{Soil Sampling and Preparation}

Soil sampling was conducted at soybean planting/after cover crop termination. Soil sub-samples from the top 0-10 cm were collected from the middle of each planted row in a plot and homogenized. Approximately $500 \mathrm{~g}$ of soil was placed in a Ziploc bag and immediately stored in a cooler. For long-term storage, samples were frozen in a $-20{ }^{\circ} \mathrm{C}$ freezer upon arrival in the laboratory. For total C, total N, POXC, EE-GRSP, WSA and pH, a soil sample was air-dried overnight, ground, passed through a $2.0 \mathrm{~mm}$ sieve and stored at room temperature [59].

\subsection{Soil Analyses}

For total soil $\mathrm{C}$ and total nitrogen $(\mathrm{N})$, one gram of air-dried soil sample was sent to the MSU soil testing lab and measurement was done with a dry combustion analyzer. For this method, samples were weighed in a crucible and introduced to a resistance furnace. Samples were oxidized above $950{ }^{\circ} \mathrm{C}$ under purified oxygen [60] and converted to $\mathrm{CO}_{2}$ and $\mathrm{N}_{2}$, which was detected by an $\mathrm{N}_{2}$ analyzer and $\mathrm{CO}_{2}$ detector. Permanganate oxidizable $\mathrm{C}$ (POXC) or active carbon (C) were measured using the procedure given by Culman et al. [37]. Briefly, air-dried soil samples $(2.5 \mathrm{~g})$ were stored in $50 \mathrm{~mL}$ polypropylene tubes, to which $18 \mathrm{~mL}$ of deionized water and $2.0 \mathrm{~mL}$ of $0.2 \mathrm{M} \mathrm{KMnO}_{4}$ stock solution were added. Tubes were shaken at 180 oscillations per minute for exactly $2 \mathrm{~min}$ and then allowed to settle for $10 \mathrm{~min}$. After $10 \mathrm{~min}, 0.5 \mathrm{~mL}$ of supernatant was transferred to a second $50 \mathrm{~mL}$ of 
the tube holding $49.5 \mathrm{~mL}$ of deionized water and mixed. The absorbance was read with a spectrophotometer at $550 \mathrm{~nm}$. POXC was calculated using the formula given by Weil et al. [39]:

$$
\operatorname{POXC}\left(\mathrm{mg} \mathrm{kg}^{-1} \text { soil }\right)=0.02 \mathrm{~mol} \mathrm{~L}^{-1}-(a+b \times a b s) \times\left(9000 \mathrm{mg} \mathrm{C} \mathrm{mol}^{-1}\right) \times\left(0.02{\left.\mathrm{~L} \mathrm{solution} \mathrm{Wt}^{-1}\right)}^{-1}\right.
$$

where $0.02 \mathrm{~mol} / \mathrm{L}=$ initial solution concentration of $\mathrm{KMnO}_{4} ; a=$ intercept of a standard curve; $b=$ slope of the standard curve; $A b s=$ unknown absorbance; $9000=$ milligrams of carbon oxidized by 1 mole of $\mathrm{MnO}_{4}$; changing from $\mathrm{Mn}^{7+} \rightarrow \mathrm{Mn}^{4+} ; 0.02 \mathrm{~L}=$ volume of reacted stock solution; $W t=$ weight of air-dried soil sample in $\mathrm{kg}$.

Easily extractable glomalin-related soil protein (EE-GRSP) was extracted from soil solution as described by Reyna and Wall [61]. One gram of air-dried soil sample was mixed with $8.0 \mathrm{~mL}$ of $20 \mathrm{mM}$ of sodium citrate ( $\mathrm{pH} 7.0)$ in a $50 \mathrm{~mL}$ centrifuge tube. Tubes were autoclaved at $121^{\circ} \mathrm{C}$ for $30 \mathrm{~min}$. Immediately after autoclaving, the tubes were centrifuged at $5000 \times g$ for $15 \mathrm{~min}$. The supernatant containing EE-GRSP was separated from the centrifuge tube. This supernatant was assayed using the Pierce Bicinchoninic Acid (BCA) Protein Assay Kit (Thermo Fisher Scientific, Waltham, MA, USA) and detected in a spectrophotometer at $562 \mathrm{~nm}$ absorbance using bovine serum albumin (BSA) as standard. For EE-GRSP determination, $100 \mu \mathrm{L}$ of supernatant was added to $2.0 \mathrm{~mL}$ of standard working reagent in a glass tube. Tubes were incubated at $37^{\circ} \mathrm{C}$ for $30 \mathrm{~min}$ and the absorbance of samples and standards was read at room temperature. The easily extractableGRSP concentration was calculated as $\mathrm{mg} / \mathrm{g}$ of dry soil. Water-stable aggregate (WSA) was measured by using the wet-sieving method [62]. Four grams of air-dried soil sample $(1.0-2.0 \mathrm{~mm})$ was placed in the sieve of a wet sieving apparatus and wet-sieved in a can of deionized water for $3.0 \mathrm{~min}$. This can was replaced by another can with a dispersing solution $(2.0 \mathrm{~g}$ of $\mathrm{NaOH} / \mathrm{L})$ and sieved until only sand particles were left in the sieve. The soil collected in the can was oven-dried overnight at $110^{\circ} \mathrm{C}$. The weight of soil in the can was measured. Water-stable aggregate was calculated using the formula below:

$$
W S A=\frac{W d s}{(W d s+W d w)} \times 100 \%
$$

where $W S A=$ water stable aggregate; $W d s$ = weight of aggregate dispersed in dispersing solution; $W d w=$ weight of aggregate dispersed in deionized water.

Soil $\mathrm{pH}$ was measured on soil:water (1:1) slurry following the procedure by Thomas [63]. Ten grams of air-dried soil sample was weighed into a $50 \mathrm{~mL}$ beaker. Ten milliliters of deionized water was added and mixed well. The soil suspension was allowed to stand for $10 \mathrm{~min}$ and soil $\mathrm{pH}$ was determined with silver chloride and a combination electrode.

For cover crop production, cover crop vegetation was collected from a $1 \mathrm{~m}^{2}$ area using a quadrat in each plot before the termination of cover crop. Samples were dried at $65^{\circ} \mathrm{C}$ for 1-2 weeks in a drier to constant weight and the final weight was recorded. Five plants were measured from each of two middle rows in all plots. Soybean was harvested from the four middle rows of each plot with a plot combine.

\subsection{Statistical Analysis}

Data were analyzed using a general linear model ANOVA to determine the effects of treatments on variables. In 2018, fertilizers were not applied until after cover crops were terminated. Therefore, cover crop production was analyzed with a one-factor experiment with a randomized complete block design. In 2019 and 2020, fertilizer source was considered as a split-plot factor due to the possibility of residual fertilizer effects on cover crop production and analyzed with a randomized complete block design with split-plot treatment structure. Total C and total N, WSA, EE-GRSP, POXC, pH and soybean yield were analyzed as a randomized complete block design with a split-plot treatment structure using cover crop as the whole plot and fertilizer as a split plot. The soybean planting dates were analyzed separately. Data were analyzed using the general linear model PROC GLIMMIX of SAS 9.4 
(SAS Institute Inc., SAS Campus Drive, Cary, NC 27513, USA) with mean values separated at the 0.05 level of probability using Fisher's protected least significance difference (LSD).

\section{Results}

This study focused on the effects of cover crops and fertilizer sources on selected biologically related soil properties, cover crop production and soybean yield. The data for no year/treatment (cover crop and fertilizer source) interaction were combined except for the effect of cover crops on cover crop production and the effect of fertilizer source on EE-GRSP (Table 5). There was no cover crop and fertilizer source interaction effect on biologically related soil properties except in terms of the soil $\mathrm{pH}$ at the late planting date. Therefore, the data were presented as the main effects of the cover crop and fertilizer source. Soybean received a total rainfall of $308 \mathrm{~mm}$ in 2018, $431 \mathrm{~mm}$ in 2019 and $512 \mathrm{~mm}$ in 2020. The rainfall in September 2018 was $161 \mathrm{~mm}$, which greatly reduced the soybean seed quality and yield. Therefore, soybean yield data from 2018 were excluded.

Table 5. Probability values ( $p$-values) and numerator of degrees of freedom (df) associated with the sources variance on soil properties and soybean yield components determined as effects of cover crop and fertilizer source in a no-tillage dryland system at Pontotoc, MS.

\begin{tabular}{|c|c|c|c|c|c|c|c|c|}
\hline Effect & Df & $\mathrm{C}\left(\mathrm{g} \mathrm{kg}^{-1}\right)$ & $N\left(g_{k g}^{-1}\right)$ & WSA \% & $\begin{array}{l}\text { EE-GRSP } \\
\left(\mathrm{mg} \mathrm{g}^{-1}\right)\end{array}$ & $\begin{array}{c}\text { POXC } \\
\left(\mathrm{mg} \mathrm{kg}^{-1}\right)\end{array}$ & $\mathrm{pH}$ & $\begin{array}{c}\text { Yield } \\
\left(\mathrm{kg} \mathrm{ha}^{-1}\right)\end{array}$ \\
\hline \multicolumn{9}{|c|}{ Early Planting Date } \\
\hline $\mathrm{Y}^{1}$ & 2 & $<0.0390$ & 0.0413 & $<0.0001$ & 0.0097 & 0.0075 & $<0.001$ & $<0.001$ \\
\hline $\mathrm{CC}$ & 4 & $<0.2452$ & 0.1466 & 0.3696 & 0.2566 & 0.5448 & 0.0123 & 0.4356 \\
\hline $\mathrm{Y}^{* 2} \mathrm{CC}$ & 8 & 0.9997 & 1.0000 & 0.7305 & 0.9993 & 0.9941 & 0.9579 & 0.8835 \\
\hline $\mathrm{F}$ & 2 & 0.0265 & 0.0002 & 0.0978 & 0.2134 & 0.0066 & 0.0044 & $<0.0001$ \\
\hline $\mathrm{Y}^{*} \mathrm{~F}$ & 4 & 0.6733 & 0.7078 & 0.7682 & 0.8216 & 0.4450 & 0.1176 & $<0.0001$ \\
\hline $\mathrm{CC}^{*} \mathrm{~F}$ & 8 & 0.4397 & 0.3402 & 0.1950 & 0.3836 & 0.0462 & 0.0797 & 0.2760 \\
\hline $\mathrm{Y}^{*} \mathrm{CC}^{*} \mathrm{~F}$ & 16 & 0.1640 & 0.2622 & 0.7265 & 0.3456 & 0.3407 & 0.9422 & 0.9361 \\
\hline \multicolumn{9}{|c|}{ Late Planting Date } \\
\hline $\mathrm{Y}$ & 2 & $<0.001$ & $<0.001$ & 0.0002 & $<0.001$ & 0.0089 & 0.0006 & 0.0686 \\
\hline $\mathrm{CC}$ & 4 & 0.8794 & 0.7914 & 0.5534 & 0.7464 & 0.9088 & 0.2786 & 0.3837 \\
\hline $\mathrm{Y}^{*} \mathrm{CC}$ & 8 & 0.9003 & 0.9331 & 0.3842 & 0.9904 & 0.3723 & 0.9593 & 0.9631 \\
\hline F & 2 & 0.0189 & 0.0004 & 0.3615 & $<0.001$ & 0.0276 & 0.0006 & $<0.001$ \\
\hline $\mathrm{Y}^{*} \mathrm{~F}$ & 4 & 0.4436 & 0.4131 & 0.0085 & 0.0366 & 0.2616 & 0.2463 & 0.0404 \\
\hline $\mathrm{CC}^{*} \mathrm{~F}$ & 8 & 0.4647 & 0.3534 & 0.1986 & 0.0419 & 0.4682 & $<0.001$ & 0.9979 \\
\hline $\mathrm{Y}^{*} \mathrm{CC}^{*} \mathrm{~F}$ & 16 & 0.8793 & 0.7221 & 0.7623 & 0.8709 & 0.9692 & 0.0971 & 0.3407 \\
\hline
\end{tabular}

${ }^{1}$ Abbreviations: $\mathrm{C}=$ total carbon; $\mathrm{N}=$ total nitrogen; $\mathrm{WSA}=$ water stable aggregate; EE-GRSP = easily extractable-glomalin-related soil protein; $\mathrm{POXC}=$ permanganate oxidizable carbon; $\mathrm{LAI}=$ leaf area index; $\mathrm{Y}=$ year; $\mathrm{CC}=$ cover crop; $\mathrm{F}=$ fertilizer source and ${ }^{2}$ Interaction between factors.

\subsection{Cover Crop Production}

Cover crop production in the early-terminated cover crop was higher in 2019 compared to 2018 and 2020. This could be due to the abundant rainfall in the spring and nutrient carry-over in soil and plant residue from 2018. The yields of wheat, CC-mix and cereal rye biomass were greater than native vegetation and vetch in both early and late-terminated cover crops (Table 4). Biomass yield with vetch and native vegetation was not different (Table 4). Cover crop production was higher with late termination because it was allowed to grow for approximately 4 weeks longer compared to the early-terminated cover crop. In addition, fertilizer was applied to both early and late planting dates at the early planting termination. This would also have benefited the growth of cover crops in the late-terminated cover crop during this four-week time period. In 2019, cover crop production was not different from native vegetation in both early (ranged from 1953 to $3639 \mathrm{~kg} \mathrm{ha}^{-1}$ ) and late-terminated cover crops (ranged from 2989 to $4408 \mathrm{~kg} \mathrm{ha}^{-1}$ ) (Table 4). However, vetch biomass was lower compared to other cover crops at early termination. 
Overall, cover crop production were typically higher than native vegetation except at early termination in 2019 (Table 4).

In 2018, cover crop production was collected only from no-fertilizer plots. Fertilizer source showed no effect on cover crop production in 2019 but had a significant effect in 2020 (Figure 1). In early-terminated cover crop, cover crop production accumulation was high with poultry litter $\left(2195 \mathrm{~kg} \mathrm{ha}^{-1}\right)$ and inorganic fertilizer $\left(1966 \mathrm{~kg} \mathrm{ha}^{-1}\right)$ compared to no fertilizer $\left(993 \mathrm{~kg} \mathrm{ha}^{-1}\right)(p<0.0001)$ (Figure 1a) in 2020. In late-terminated cover crop, the highest cover crop production was with poultry litter $\left(4056 \mathrm{~kg} \mathrm{ha}^{-1}\right)$ followed by inorganic fertilizer (3233 $\left.\mathrm{kg} \mathrm{ha}^{-1}\right)$ compared to no fertilizer in $2020\left(2152 \mathrm{~kg} \mathrm{ha}^{-1}\right)$ $(p<0.0001)$ (Figure 1b). The biomass accumulation was higher in late-terminated cover crop compared to early-terminated cover crop.
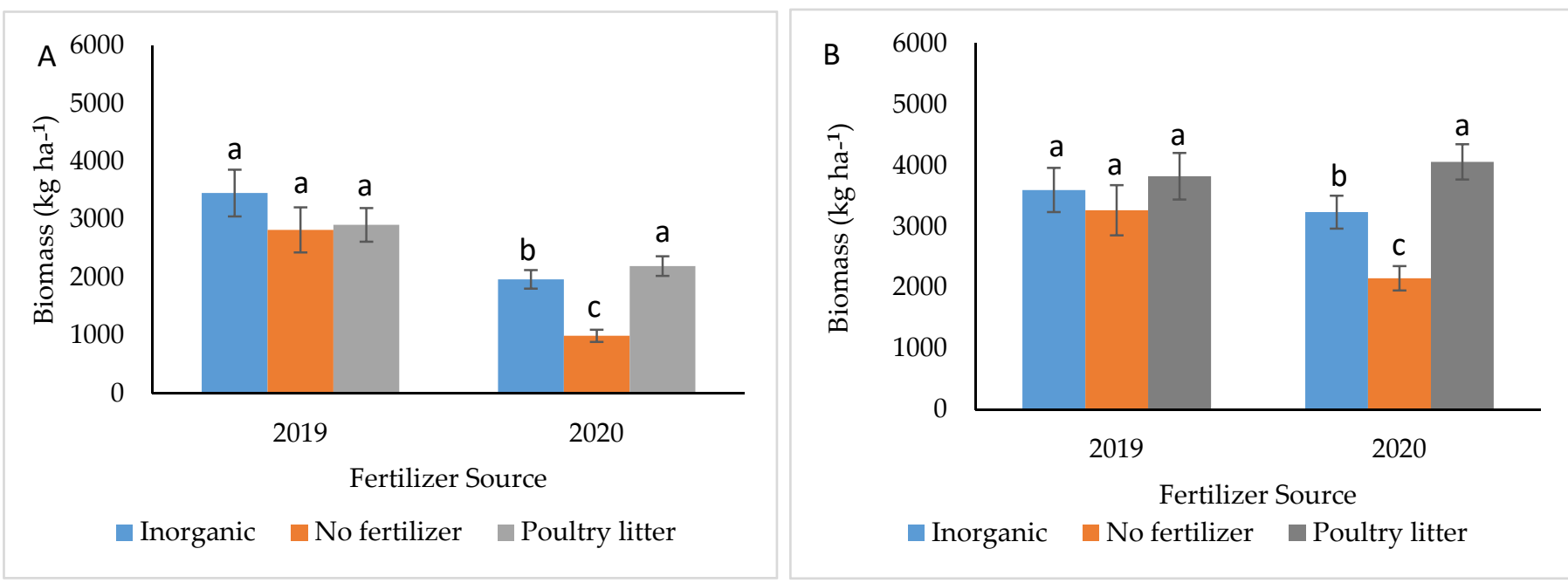

Figure 1. Fertilizer source effect on cover crop production in 2019 and 2020: (A) in early-terminated cover crop; (B) in late-terminated cover crop. Different letters indicate significant differences at $p \leq 0.05$.

\subsection{Total Carbon and Total Nitrogen}

Including cover crops in farming showed no effect on total $\mathrm{C}$ and total $\mathrm{N}$ in both early and late planting dates (Table 6). Total $\mathrm{C}$ ranged from $11.8\left(\mathrm{~g} \mathrm{~kg}^{-1}\right)$ to $18.3\left(\mathrm{~g} \mathrm{~kg}^{-1}\right)$ in early planting date and $17.2\left(\mathrm{~g} \mathrm{~kg}^{-1}\right)$ to $18.0\left(\mathrm{~g} \mathrm{~kg}^{-1}\right)$ in late planting date. Total $\mathrm{N}$ ranged from $1.6\left(\mathrm{~g} \mathrm{~kg}^{-1}\right)$ to $1.9\left(\mathrm{~g} \mathrm{~kg}^{-1}\right)$ and $1.8\left(\mathrm{~g} \mathrm{~kg}^{-1}\right)$ to $1.9\left(\mathrm{~g} \mathrm{~kg}^{-1}\right)$ in early and late planting dates, respectively. With increases in cover crop production, higher organic matter addition, an increase in total $\mathrm{C}$ and total $\mathrm{N}$ was expected especially in the late planting date. Total $\mathrm{C}$ was not influenced by poultry litter and inorganic fertilizer. Total $\mathrm{N}$ content was $6 \%$ higher with poultry litter compared to no fertilizer $(p<0.0018)$. Inorganic fertilizer had a similar effect on total $\mathrm{N}$ compared to no fertilizer, indicating less effect of inorganic fertilizer on total $\mathrm{N}$ than poultry litter. In the late planting date, poultry litter influenced the total $\mathrm{N}$ by $11 \%$ compared to no fertilizer $(p<0.0197)$ (Table 7$)$. The effect of inorganic fertilizer was similar to both poultry litter and no fertilizer. 
Table 6. Main effects of cover crop on mean soil total carbon (C), total nitrogen (N), permanganate oxidizable carbon (POXC), easily extractable glomalin-related soil protein (EE-GRSP), water-stable aggregate (WSA), soil pH and soybean yield with $p$-value at early and late planting dates.

\begin{tabular}{|c|c|c|c|c|c|c|c|}
\hline Cover Crop & $\begin{array}{l}\text { Total } C^{1} \\
\left(g^{1} g^{-1}\right)\end{array}$ & $\begin{array}{l}\text { Total N } \\
\left(\mathrm{g} \mathrm{kg}^{-1}\right)\end{array}$ & $\begin{array}{c}\text { POXC } \\
\left(\mathrm{mg} \mathrm{kg}^{-1}\right)\end{array}$ & $\begin{array}{l}\text { EE-GRSP } \\
\left(\mathrm{mg} \mathrm{g}^{-1}\right)\end{array}$ & $\begin{array}{c}\text { WSA } \\
\%\end{array}$ & $\mathrm{pH}$ & $\begin{array}{c}\text { Yield } \\
\left(\mathrm{kg} \mathrm{ha}^{-1}\right)\end{array}$ \\
\hline \multicolumn{8}{|c|}{ Early-Planting Date } \\
\hline Cereal Rye & $17.1(0.6)$ & $1.7(0.0)$ & $595(26)$ & $89(3)$ & $54(32)$ & $5.84(0.07)$ & 3641 (293) \\
\hline CC-mix ${ }^{2}$ & $18.3(0.6)$ & $1.9(0.1)$ & $598(24)$ & $97(3)$ & $54(2)$ & $5.75(0.07)$ & $3787(251)$ \\
\hline Native Veg. ${ }^{3}$ & $16.0(0.5)$ & $1.6(0.1)$ & $541(18)$ & $89(2)$ & $56(2)$ & $5.94(0.07)$ & $3790(257)$ \\
\hline Vetch & $11.8(0.7)$ & $1.9(0.1)$ & $560(22)$ & $89(3)$ & $54(2)$ & $5.63(0.07)$ & $3773(269)$ \\
\hline Wheat & $16.0(0.5)$ & $1.6(0.0)$ & $537(21)$ & $87(3)$ & $51(2)$ & $5.94(0.06)$ & $3623(291)$ \\
\hline$p$-value & 0.6306 & 0.5288 & 0.8171 & 0.6101 & 0.5093 & 0.1708 & 0.9538 \\
\hline \multicolumn{8}{|c|}{ Late-Planting Date } \\
\hline Cereal Rye & $17.7(0.7)$ & $1.9(0.1)$ & $580(22)$ & $83(3)$ & $61(2)$ & $5.71(0.06)$ & $3228(136)$ \\
\hline CC-mix & $17.4(0.7)$ & $1.9(0.1)$ & $562(20)$ & $80(3)$ & $59(2)$ & $5.76(0.09)$ & $3160(130)$ \\
\hline Native Veg. & $17.2(0.6)$ & $1.8(0.0)$ & $548(22)$ & $80(3)$ & $57(1)$ & $5.89(0.10)$ & 2993 (137) \\
\hline Vetch & $17.7(0.7)$ & $1.9(0.1)$ & $564(23)$ & $82(4)$ & $59(2)$ & $5.64(0.09)$ & $3222(145)$ \\
\hline Wheat & $18.0(0.7)$ & $1.9(0.1)$ & $578(24)$ & $77(2)$ & $60(1)$ & $5.82(0.08)$ & 2995 (133) \\
\hline$p$-value & 0.9705 & 0.9389 & 0.8477 & 0.9037 & 0.5268 & 0.7360 & 0.6624 \\
\hline
\end{tabular}

Table 7. Main effects of fertilizer source on soil total carbon $(\mathrm{C})$, total nitrogen $(\mathrm{N})$, permanganate oxidizable carbon (POXC), easily extractable glomalin-related soil protein (EE-GRSP), water stable aggregate (WSA) and soil $\mathrm{pH}$.

\begin{tabular}{|c|c|c|c|c|c|c|}
\hline $\begin{array}{l}\text { Fertilizer } \\
\text { Source }\end{array}$ & $\begin{array}{l}\text { Total C } \\
\left(\mathrm{g} \mathrm{kg}^{-1}\right)\end{array}$ & $\begin{array}{l}\text { Total N } \\
\left(\mathrm{g} \mathrm{kg}^{-1}\right)\end{array}$ & $\begin{array}{c}\text { POXC } \\
\left(\mathrm{mg} \mathrm{kg}^{-1}\right)\end{array}$ & $\begin{array}{l}\text { EE-GRSP } \\
\left(\mathrm{mg} \mathrm{g}^{-1}\right)\end{array}$ & $\begin{array}{c}\text { WSA } \\
\%\end{array}$ & $\mathrm{pH}$ \\
\hline \multicolumn{7}{|c|}{ Early-Planting Date } \\
\hline Inorganic & $16.8(0.5)^{2} a$ & $1.7(0.0) \mathrm{b}$ & $558(23) \mathrm{a}$ & 89 (2) a & $52(2) \mathrm{a}$ & $5.76(0.06) \mathrm{a}$ \\
\hline $\begin{array}{c}\text { No } \\
\text { Fertilizer }\end{array}$ & $16.7(0.5) \mathrm{a}$ & $1.7(0.0) b$ & $550(15) \mathrm{a}$ & 89 (2) a & $54(2) \mathrm{a}$ & $5.90(0.05) \mathrm{a}$ \\
\hline $\begin{array}{c}\text { Poultry } \\
\text { Litter }\end{array}$ & $17.8(0.5) \mathrm{a}$ & $1.8(0.0) \mathrm{a}$ & $592(18)$ a & $93(2) \mathrm{a}$ & $55(2) \mathrm{a}$ & $5.80(0.05) \mathrm{a}$ \\
\hline$p$-value & 0.0727 & 0.0018 & 0.0843 & 0.2672 & 0.2297 & 0.1296 \\
\hline \multicolumn{7}{|c|}{ Late-Planting Date } \\
\hline Inorganic & $17.6(0.5) \mathrm{a}$ & $1.9(0.0) b$ & 557 (15) a & $80(2) b$ & 60 (1) a & $5.71(0.07) b$ \\
\hline $\begin{array}{c}\text { No } \\
\text { Fertilizer }\end{array}$ & $17.0(0.5) \mathrm{a}$ & $1.8(0.0) \mathrm{ab}$ & $550(18) a$ & $75(2) b$ & 59 (1) a & $5.91(0.07) \mathrm{a}$ \\
\hline $\begin{array}{l}\text { Poultry } \\
\text { Litter }\end{array}$ & $18.3(0.5) \mathrm{a}$ & $2.0(0.0) \mathrm{a}$ & $580(16) \mathrm{a}$ & $85(2) a$ & $58(1) \mathrm{a}$ & $5.66(0.06) b$ \\
\hline$p$-value & 0.1962 & 0.0197 & 0.3629 & 0.0010 & 0.5973 & 0.0030 \\
\hline
\end{tabular}

${ }^{1}$ Variables with different letters in column are significantly different and variables with same letter are not significant at the 0.05 level using Fisher's protected LSD; ${ }^{2}$ Standard error in parenthesis.

\subsection{Permanganate Oxidizable Carbon}

Both cover crop and fertilizer showed no significant effect on POXC in early and late planting dates (Tables 6 and 7). The POXC in early planting date ranged from 537 to $598 \mathrm{mg} \mathrm{kg}^{-1}$ and in late planting date it ranged from 546 to $580 \mathrm{mg} \mathrm{kg}^{-1}$. It was expected that POXC would be higher in cover crops plots compared to the native vegetation plots.

\subsection{Easily Extractable Glomalin-Related Soil Protein}

Easily extractable glomalin-related soil protein (EE-GRSP) was not influenced by cover crops in both planting dates. Fertilizer source showed a significant effect on EE-GRSP in late planting date. In the late planting date, with poultry litter addition, EE-GRSP increased 
by $13 \%$ compared to no fertilizer $(p<0.001)$ (Table 7$)$. There was no difference between the no-fertilizer addition and inorganic fertilizer treatments in either planting date group (Table 7). Cover crops showed no effect on EE-GRSP in three years of study while poultry litter showed an effect on late planting date. This may be because of the availability of energy from poultry litter for a longer period than an early planting date.

\subsection{Water Stable Aggregate}

There was no difference in water stable aggregates (WSA) among cover crops and fertilizer sources in both early and late planting dates (Tables 6 and 7). The average WSA was 54 and $59 \mathrm{mg} \mathrm{kg}^{-1}$ in early and late planting dates. Water stable aggregates are formed by organic matter and biological activities. The biological activities and organic carbon may not be enough to show significant effects of cover crop and inorganic fertilizer in three years of study in dryland soybean farm.

\subsection{Soil $p H$}

Cover crops had no effect on soil pH in early planting (Table 6). There was cover crop and fertilizer interaction in the late planting date. Higher soil $\mathrm{pH}$ was with native vegetation $x$ no fertilizer (6.3) compared to cover crop and fertilizer interaction $(p<0.005)$. Lower soil $\mathrm{pH}$ was with vetch $\times$ poultry litter (5.3). Soil $\mathrm{pH}$ with vetch was low compared to native vegetation in both early and late planting dates. Fertilizer source did affect soil $\mathrm{pH}$ in the late planting date (Table 7). In the late planted soybean area, soil $\mathrm{pH}$ was 0.25 units lower with poultry litter compared to no fertilizer treatment (Table 7). There was no difference between no fertilizer and poultry litter treatment (Table 7). Inorganic fertilizer and no fertilizer effect were similar. In the poultry litter applied plots, cover crop growth was relatively higher than no fertilizer.

\subsection{Soybean Yield}

Cover crops did not affect soybean yield in both early and late-planted soybeans in the three years of the study (Table 6). The use of fertilizer had a positive effect on both early and late planting dates. At the early planting date, the yield increased by $68 \%$ and $51 \%$ with poultry litter and inorganic fertilizer compared to no fertilizer, respectively (Figure 2a). Soybean yield with poultry litter and inorganic fertilizer increased by $42 \%$ and $40 \%$ compared to no fertilizer in late-planted soybean, respectively (Figure 2b).
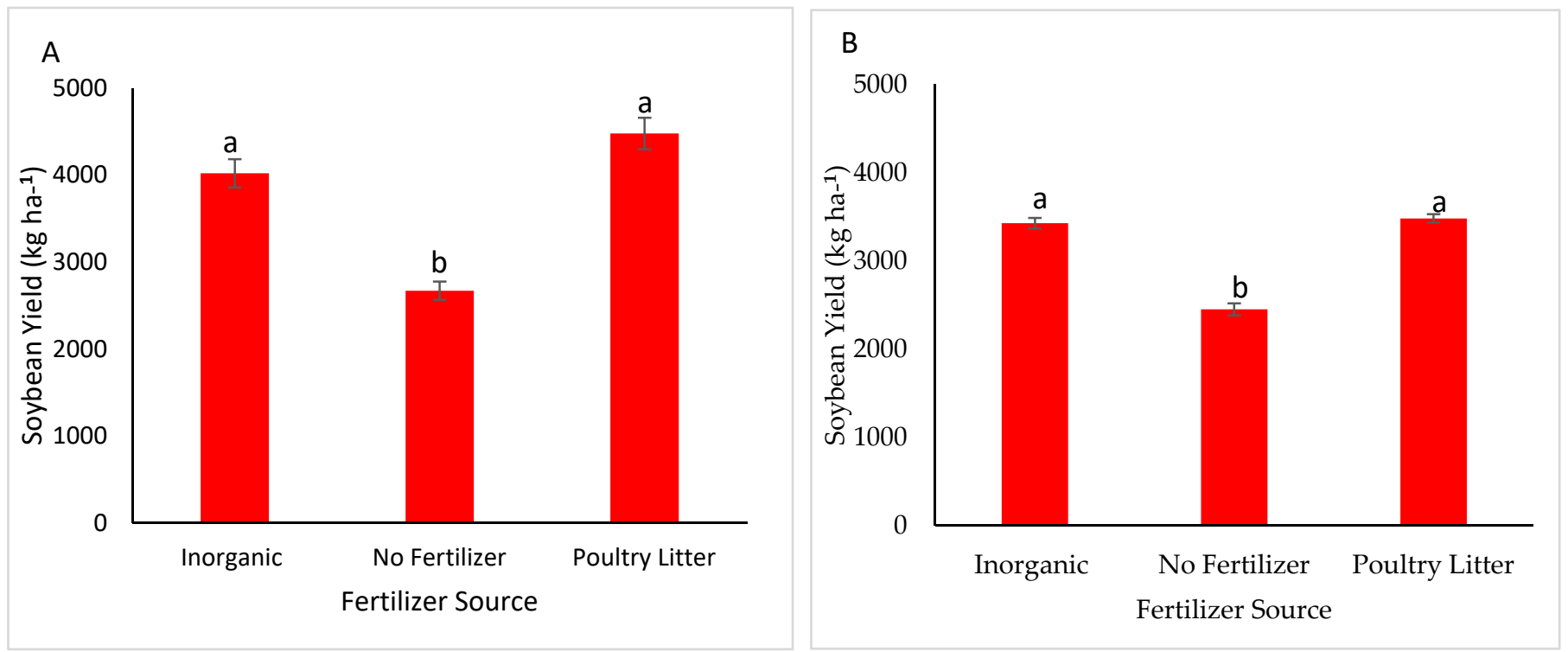

Figure 2. Fertilizer source effect on soybean yield (A) early planting date and (B) late planting date. The soybean yield is the average of two years (2019 and 2020). In 2018, heavy rainfall greatly reduced the soybean yield and thus these data were not included. Different letters indicate significant differences at $p \leq 0.05$. 


\section{Discussion}

\subsection{Cover Crop Production}

The variation in rainfall and temperature might be a possible reason for the variation in biomass yield between years [64]. Furthermore, the selected mustard variety had low cold-tolerance in the fall of 2017 and it did not survive through the winter months to serve as a cover crop in 2018. The increased cover crop production in 2019 could be due to the high rainfall during the cover crop growth period. More biomass in cereal rye and wheat compared to native vegetation was also reported by Lawson et al. [21], where the biomass with rye and rye-vetch mix was on average $62 \%$ higher compared to vetch alone on Briscot loam in a six-year study near Washington State University. In addition, the biomass yield was higher with late versus early-terminated cover crop, which was also similar to the results of Lawson et al. [21]. Other research indicates that an accumulation of cover crop production in the soil surface will increase organic matter [23]. In a dryland system, the addition of organic matter could increase the water-holding capacity because it can retain about 20 times more water than its weight [65]. Our results showed that, overall, cereal rye, CC-mix and wheat added more cover crop biomass to the soil compared to native vegetation.

\subsection{Total Carbon and Nitrogen}

Total $\mathrm{C}$ was expected to be high at the late planting date compared to the early planting date due to the accumulation of more cover crop biomass. Total $\mathrm{N}$ when poultry litter was applied was $11 \%$ higher than the no-fertilizer and inorganic fertilizer treatments (Table 7). Similar results with no considerable effects of cover crop on total $C$ and total $N$ were reported by Acuna and Villamil [66] in two locations in Illinois. Olson et al. [67] reported no effect of cover crops on $C$ content in an eight-year study. Watts et al. [68] also reported higher $\mathrm{N}$ accumulation with poultry litter in northeast Alabama. However, some cover crop studies showed an increase in total $\mathrm{C}$ and total $\mathrm{N}$ in short-term studies. Tao et al. [68] observed increased soil organic matter and total $\mathrm{N}$ with the addition of hairy vetch on a loam soil. Muchanga et al. [69] reported a 3\% increase in C content over a two-year period with hairy vetch as a cover crop in a high-tunnel tomato system. Harun [70] showed a $26 \%$ increase in soil organic $C$ with winter wheat compared to control in a laboratory study on a Cumberland silt loam (fine, mixed, semiactive, thermic Rhodic Paleudalfs) in Tennessee. Garcia-Gonzalez et al. [71] showed increased C and N with barley and vetch cover crop in a 10 year study on irrigated Topic Calcisol soil. This contrast with our results might be due to the slow effects of cover crop on total $\mathrm{C}$ and total $\mathrm{N}$ in a dryland system. Cover crops supply a $\mathrm{C}$ energy source to soil microbes and after cover crop termination, soil microbes decompose the crop residue. During the cover crop decomposition process, soil microbes respire large amounts of $\mathrm{CO}_{2}$ and only a small fraction of $\mathrm{C}$ is added to the soil, which results in a slow build-up of total C [72]. Another reason could be the rapid mineralization of $C$ due to the soil type and the hot and humid climate of Mississippi [53,73]. This shortterm field study was subjected to various other factors such as irregular rainfall patterns and temperature variations, which could also be a reason that the results from our study disagree with others. In addition, the study used a no-tillage system, meaning that the cover crop production was not incorporated into the soil and the sample was collected after removing the surface biomass and this results in a reduced effect of cover crop on soil C. Adeli et al. [74] reported a 19\% increase in total C with poultry litter compared to no-added-fertilizer treatments on this soil at the same branch station over three years. Parker et al. [75] also reported increased total $C$ in soil over a four-year period with poultry litter and cover crops in Alabama, suggesting a longer time frame may be necessary to see a difference in treatments. We were applying about $3.2 \mathrm{~g}^{\circ} \mathrm{N} \mathrm{kg}^{-1}$ of poultry litter and the increased $\mathrm{N}$ content with poultry litter in our study might be due to the build-up of $\mathrm{N}$ over time since an average of $40-70 \%$ of the nitrogen in poultry litter is released within six weeks of application and soil samples were collected after four weeks of poultry litter application [75]. 


\subsection{Permanganate Oxidizable Carbon}

Cover crop and fertilizer source had no effect on permanganate oxidizable C (POXC) content at both planting dates. These results agree with Jagadamma et al. [76] who reported no difference in POXC in the top $15 \mathrm{~cm}$ but they did see a difference in the top $0-7.5 \mathrm{~cm}$ of soil with crop rotation and cover crop management practices at three locations in Tennessee. White et al. [77] reported a $26 \%$ increase in POXC with cover crop and manure in California after eight years of study and Jokela et al. [78] observed increases in POXC with cover crop but no effect with manure addition on a Bertrand silt loam after 13 years study in Wisconsin. Steele et al. [79] also reported a significant effect on POXC with cover crop in a no-tillage system on Coastal Plains silt loam but not on Piedmont line loam after 12 years. Soil texture directly influences $C$ content in the soil and POXC is a fraction of $C[80,81]$. In clay soils, POXC binds to clay particles and makes it less available to soil microbes but in sandy and silty soils, POXC is easily available to soil microbes for conversion into more stable $C$ forms [82]. The reason for the lack of an effect could be due to the increased microbial abundance by treatments that could have rapidly oxidized and transformed POXC to a stable form of soil organic C [82].

\subsection{Easily Extractable Glomalin-Like Soil Protein}

Cover crops had no influence on easily extractable-glomalin-related soil protein (EEGRSP) at both early and late planting dates. However, Garcia-Gonzalez et al. [50] reported increased EE-GRSP with a vetch-barley mix compared to fallow after two years. Balota et al. [83] also observed a 50\% increase in EE-GRSP with a cover crop and no-tillage system after 23 years. Precipitation directly affects the AMF hyphal length, a warm moist environment can greatly influence AMF population and decline hyphae viability $[84,85]$. Since EE-GRSP is produced in hyphae, a decline in hyphae viability reduces EE-GRSP production. High moisture reduces AMF population; the reason for this could be the decreased availability of energy sources for AMF and other anaerobic fungi may have suppressed AMF population [86].

Fertilizer sources showed a significant effect on EE-GRSP in late-planted soybean areas. EE-GRSP is produced by AMF and it works as a binding agent of water-stable aggregate, which makes it an indirect method of predicting soil aggregation and fungal population. Studies have shown a correlation between EE-GRSP and AMF [87-89]. About one-third of soil microbial biomass is occupied by AMF and its activity influences EE-GRSP production [90]. Zhang et al. [51] reported that poultry litter improved fungal energy sources and habitat and enhanced hyphae development for EE-GRSP production.

\subsection{Water Stable Aggregate}

There was no difference in water-stable aggregates (WSA) among cover crops and fertilizer sources at both early and late planting dates (Tables 6 and 7). Sanchez de Cima et al. [56] reported decreased WSA due to high rainfall. Irregular rainfall with varied intensity dispersed soil particles and reduced soil aggregation [91]. There was irregular and highly intensive rainfall in 2019, which could have been a reason for the reduction in WSA (Table 1). Another reason for reduced WSA could be the high rate of organic matter decomposition by soil microbes in the second year. Hetrick et al. [91] reported a lower level of soil aggregation with a decrease in organic matter. Song et al. [92] noted an accumulation of $C$ due to crop residue left on the soil surface with no-tillage, which increased WSA by $35.18 \%$ compared to conventional tillage after three years on estuarine alluvial soil. In another study, WSA increased by $55 \%$ with a cereal rye compared to no cover crop in southeast Indiana [93]. The addition of organic matter from cover crops acts as a binding agent for soil particles but the amount of organic matter added to soil in our study may not have been high enough to promote WSA content in a two-year study [94].

WSA content was influenced by fertilizer source. Our study disagreed with statements by USDA-NRCS [95] and Liu et al. [46] who reported that WSA improves with high C, EE-GRSP and more biological activity with poultry litter, as these are binding agents of soil 
particles. Soil biological activities are responsible for the formation of soil aggregates [96]. The increased WSA with poultry litter may be due to the high POXC, which provides a readily available source of energy for soil microbes to catalyze their activities [97]. Another reason might be the higher production of EE-GRSP with poultry litter that binds the soil particles [45]. Furthermore, soil microbial mycelia and root mucilage boost aggregation [98]. Adeli et al. [74] reported a 7\% increase in WSA with poultry litter compared to no fertilizer on Atwood loam after four years in a no-tillage system. The shorter period of our study might be a reason for the lack of effects of cover crop and fertilizer source on WSA.

\subsection{Soil $p H$}

The soil $\mathrm{pH}$ did not show a significant difference among the treatment plots over the three years study. Vetch-poultry litter plots showed a modest low $\mathrm{pH}$ compared to no fertilizer-native vegetation treatment, which was not consistent among planting dates and years. Vetch produces ammonia by using $\mathrm{N}$ from the air rather than the soil, resulting in a lower soil $\mathrm{pH}$, which might be a reason for the lower $\mathrm{pH}$ with vetch [99]. The results of this study was in agreement with Liebig et al. [64], who reported no effect of summer cover crops on soil $\mathrm{pH}$ after three years of late-seeded cover crops.

\subsection{Soybean Yield}

Cover crops did not affect soybean yield in both early and late-planted soybeans in our three years study period. Similar results were found by Acuna and Villamil [66] and our results also agreed with Freitas et al. [100] who showed that the use of cover crops did not affect the no-till soybean yield on Rhodic Hapludox soil in a dryland system. Fertilizer use showed a significant effect on soybean yield for both early and late-planted soybean. Similar results were reported by Ayolagha and Peter [101] on Ultisols of Ogoni land in the Niger Delta. Our results suggest that the impact of cover crops and fertilizer on biologically related soil properties was strongly influenced by rainfall and temperature during the growing period.

\section{Conclusions}

This study represents, to our knowledge, one of the few studies on the cover crop and planting date impacts on biologically related soil properties in dryland soybean production in the southeastern USA. The main goal of this study was to evaluate the agronomic impacts of winter cover crops, soybean planting date and fertilizer management on soil properties. Soybean yields were not affected by cover crop and fertility treatments, perhaps because the agronomic benefits of these practices on dryland soybean production may take several years to appear. While the short-term effects of cover crop and organic fertilizer combinations appear promising with respect to soil fertility and yield, additional long-term experiments in no-tillage dryland soybean production are clearly needed.

Author Contributions: Conceptualization, M.W.S.; methodology, S.G.S., W.L.K.; investigation, M.W.S., W.L.K., S.G.S.; writing—original draft, S.P.; writing—review and editing, S.G.S., W.L.K., M.W.S and M.S.C.; supervision, M.W.S and S.G.S.; data curation and visualization, S.G.S. and S.P; formatting and submission, S.G.S.; funding acquisition, M.W.S. All authors have read and agreed to the published version of the manuscript.

Funding: This research was funded through the Mississippi Soybean Promotion Board (MSPB), project number 21-2020, awarded to Mark W. Shankle.

Institutional Review Board Statement: Not Applicable.

Informed Consent Statement: Not Applicable.

Data Availability Statement: The data presented in this study are available on request from the corresponding author.

Acknowledgments: We appreciate all the staffs at Pontotoc Ridge-Flatwoods Branch Experiment Station, Pontotoc, MS, USA for their help in experimental site setup and field operations. 
Conflicts of Interest: The authors declare no conflict of interest.

\section{References}

1. Pejić, B.; Maksimović, L.; Cimpeanu, S.; Bucur, D.; Milić, S.; Ćupina, B. Response of soybean to water stress at specific growth stages. J. Food Agric. Environ. 2011, 9, 280-284.

2. Orlowski, J. Maximization of Yield and Economic Returns for Non-Irrigated Soybean Production in Mississippi. Available online: https: / / www.mssoy.org/uploads/files/2016-project-synopses.pdf (accessed on 24 January 2020).

3. Holzman, M.E.; Rivas, R.; Piccolo, M.C. Estimating soil moisture and the relationship with crop yield using surface temperature and vegetation index. Int. J. Appl. Earth Obs. Geoinf. 2014, 28, 181-192. [CrossRef]

4. Hill, C.C.; Robinson, L.A. Potentiometric Map of the Ripley Aquifers in Northeastern Mississippi; Branch, C.T., Ed.; Mississippi Department of Environmental Quality Office of Land and Water Resources: Jackson, MS, USA, 1994.

5. Kühling, I.; Redozubov, D.; Broll, G.; Trautz, D. Impact of tillage, seeding rate and seeding depth on soil moisture and dryland spring wheat yield in Western Siberia. Soil Tillage Res. 2017, 170, 43-52. [CrossRef]

6. Lampurlanés, J.; Plaza-Bonilla, D.; Álvaro-Fuentes, J.; Cantero-Martínez, C. Long-term analysis of soil water conservation and crop yield under different tillage systems in Mediterranean rainfed conditions. Field Crop. Res. 2016, 189, 59-67. [CrossRef]

7. Blanco-Canqui, H.; Holman, J.D.; Schlegel, A.J.; Tatarko, J.; Shaver, T.M. Replacing fallow with cover crops in a semiarid soil: Effects on soil properties. Soil Sci. Soc. Am. J. 2013, 77, 1026-1034. [CrossRef]

8. Nivelle, E.; Verzeaux, J.; Habbib, H.; Kuzyakov, Y.; Decocq, G.; Roger, D.; Lacoux, J.; Duclercq, J.; Spicher, F.; Nava-Saucedo, J.E.; et al. Functional response of soil microbial communities to tillage, cover crops and nitrogen fertilization. Appl. Soil Ecol. 2016, 108, 147-155. [CrossRef]

9. Blanco-Canqui, H.; Mikha, M.M.; Presley, D.R.; Claassen, M.M. Addition of Cover Crops Enhances No-Till Potential for Improving Soil Physical Properties. Soil Sci. Soc. Am. J. 2011, 75, 1471-1482. [CrossRef]

10. Frasier, I.; Quiroga, A.; Noellemeyer, E. Effect of different cover crops on C and N cycling in sorghum NT systems. Sci. Total Environ. 2016, 562, 628-639. [CrossRef]

11. Villamil, M.B.; Bollero, G.A.; Darmody, R.G.; Simmons, F.W.; Bullock, D.G. No-Till Corn/Soybean Systems Including Winter Cover Crops. Soil Sci. Soc. Am. J. 2006, 70, 1936-1944. [CrossRef]

12. Sievers, T.; Cook, R.L. Aboveground and root decomposition of cereal rye and hairy vetch cover crops. Soil Sci. Soc. Am. J. 2018, 82, 147-155. [CrossRef]

13. Hontoria, C.; García-González, I.; Quemada, M.; Roldán, A.; Alguacil, M.M. The cover crop determines the AMF community composition in soil and in roots of maize after a ten-year continuous crop rotation. Sci. Total Environ. 2019, 660, 913-922. [CrossRef] [PubMed]

14. Martínez-García, L.B.; Korthals, G.; Brussaard, L.; Jørgensen, H.B.; De Deyn, G.B. Organic management and cover crop species steer soil microbial community structure and functionality along with soil organic matter properties. Agric. Ecosyst. Environ. 2018, 263, 7-17. [CrossRef]

15. Nair, A.; Ngouajio, M. Soil microbial biomass, functional microbial diversity, and nematode community structure as affected by cover crops and compost in an organic vegetable production system. Appl. Soil Ecol. 2012, 58, 45-55. [CrossRef]

16. Mbuthia, L.W.; Acosta-Martínez, V.; DeBryun, J.; Schaeffer, S.; Tyler, D.; Odoi, E.; Mpheshea, M.; Walker, F.; Eash, N. Long term tillage, cover crop, and fertilization effects on microbial community structure, activity: Implications for soil quality. Soil Biol. Biochem. 2015, 89, 24-34. [CrossRef]

17. Bryant, L. AgFax: Cover Crop Planting Increased by 5 Million Acres. Available online: https://agfax.com/2019/04/16/covercrops-good-news-from-the-census-of-agriculture/ (accessed on 21 January 2020).

18. Doran, J.W.; Zeiss, M.R. Soil health and sustainability: Managing the biotic component of soil quality. Appl. Soil Ecol. 2000, 15, 3-11. [CrossRef]

19. Wagger, M.G. Time of desiccation effects on plant composition and subsequent nitrogen release from several winter annual cover crops. Agron. J. 1989, 81, 236-241. [CrossRef]

20. Dabney, S.M.; Delgado, J.A.; Reeves, D.W. Using winter cover crops to improve soil and water quality. Commun. Soil Sci. Plant Anal. 2001, 32, 1221-1250. [CrossRef]

21. Lawson, A.; Cogger, C.; Bary, A.; Fortuna, A.M. Influence of seeding ratio, planting date, and termination date on rye-hairy vetch cover crop mixture performance under organic management. PLoS ONE 2015, 10, e0129597. [CrossRef]

22. Haynes, R.J. Labile organic matter as an indicator of organic matter quality in arable and pastoral soils in New Zealand. Soil Biol. Biochem. 2000, 32, 211-219. [CrossRef]

23. Nascente, A.S.; Li, Y.C.; Crusciol, C.A.C. Cover crops and no-till effects on physical fractions of soil organic matter. Soil Tillage Res. 2013, 130, 52-57. [CrossRef]

24. Grassini, P.; Torrion, J.A.; Yang, H.S.; Rees, J.; Andersen, D.; Cassman, K.G.; Specht, J.E. Soybean yield gaps and water productivity in the western U.S. Corn Belt. Field Crop. Res. 2015, 179, 150-163. [CrossRef]

25. Ren, T.; Wang, J.; Chen, Q.; Zhang, F.; Lu, S. The effects of manure and nitrogen fertilizer applications on soil organic carbon and nitrogen in a high-input cropping system. PLoS ONE 2014, 9, e97732. [CrossRef] [PubMed]

26. Geisseler, D.; Scow, K.M. Long-term effects of mineral fertilizers on soil microorganisms-A review. Soil Biol. Biochem. 2014, 75 , 54-63. [CrossRef] 
27. Kingery, W.L.; Wood, C.W.; Williams, J.C. Tillage and amendment effects on soil carbon and nitrogen mineralization and phosphorus release. Soil Tillage Res. 1996, 37, 239-250. [CrossRef]

28. Shakya, A.; Agarwal, T. Poultry litter biochar: An approach towards poultry litter management-A review. Int. J. Curr. Microbiol. Appl. Sci. 2017, 6, 2657-2668. [CrossRef]

29. Ashworth, A.J.; DeBruyn, J.M.; Allen, F.L.; Radosevich, M.; Owens, P.R. Microbial community structure is affected by cropping sequences and poultry litter under long-term no-tillage. Soil Biol. Biochem. 2017, 114, 210-219. [CrossRef]

30. Adeli, A.; Sistani, K.R.; Rowe, D.E.; Tewolde, H. Effects of broiler litter on soybean production and soil nitrogen and phosphorus concentrations. Agron. J. 2005, 97, 314-321. [CrossRef]

31. Lin, Y.; van Santen, E.; Watts, D. The effect of poultry litter application on agricultural production: A meta-analysis of crop yield nutrient uptake and soil fertility. In Proceedings of the Conference on Applied Statistics in Agriculture; New Prairie Press: Gainesville, FL, USA, 2016.

32. Riegel, C.; Noe, J.P. Chicken litter soil amendment effects on soilborne microbes and Meloidogyne incognita on cotton. Plant Dis. 2000, 84, 1275-1281. [CrossRef]

33. Mierzwa-Hersztek, M.; Klimkowicz-Pawlas, A.; Gondek, K. Influence of Poultry Litter and Poultry Litter Biochar on Soil Microbial Respiration and Nitrifying Bacteria Activity. Waste Biomass Valoriz. 2018, 9, 379-389. [CrossRef]

34. Gaspar, A.P.; Laboski, C.A.M.; Naeve, S.L.; Conley, S.P. Phosphorus and potassium uptake, partitioning, and removal across a wide range of soybean seed yield levels. Crop Sci. 2017, 57, 2193-2204. [CrossRef]

35. Salvagiotti, F.; Cassman, K.G.; Specht, J.E.; Walters, D.T.; Weiss, A.; Dobermann, A. Nitrogen uptake, fixation and response to fertilizer N in soybeans: A review. Field Crop. Res. 2008, 108, 1-13. [CrossRef]

36. Fine, A.K.; Van Es, H.M.; Schindelbeck, R.R. Statistics, scoring functions, and regional analysis of a comprehensive soil health database. Soil Sci. Soc. Am. J. 2017, 81, 589-601. [CrossRef]

37. Culman, S.W.; Snapp, S.S.; Freeman, M.A.; Schipanski, M.E.; Beniston, J.; Lal, R.; Drinkwater, L.E.; Franzluebbers, A.J.; Glover, J.D.; Stuart Grandy, A.; et al. Permanganate oxidizable carbon reflects a processed soil fraction that is sensitive to management. Soil Sci. Soc. Am. J. 2012, 76, 494-504. [CrossRef]

38. Mitchell, J.P.; Shrestha, A.; Mathesius, K.; Scow, K.M.; Southard, R.J.; Haney, R.L.; Schmidt, R.; Munk, D.S.; Horwath, W.R. Cover cropping and no-tillage improve soil health in an arid irrigated cropping system in California's San Joaquin Valley, USA. Soil Tillage Res. 2017, 165, 325-335. [CrossRef]

39. Weil, R.R.; Islam, K.R.; Stine, M.A.; Gruver, J.B.; Samson-Liebig, S.E. Estimating active carbon for soil quality assessment: A simplified method for laboratory and field use. Am. J. Altern. Agric. 2003, 18, 3-17. [CrossRef]

40. Lovelock, C.E.; Wright, S.F.; Clark, D.A.; Ruess, R.W. Soil stocks of glomalin produced by arbuscular mycorrhizal fungi across a tropical rain forest landscape. J. Ecol. 2004, 92, 278-287. [CrossRef]

41. Janos, D.P.; Garamszegi, S.; Beltran, B. Glomalin extraction and measurement. Soil Biol. Biochem. 2008, 40, 728-739. [CrossRef]

42. Wright, S.F.; Upadhyaya, A. A survey of soils for aggregate stability and glomalin, a glycoprotein produced by hyphae of arbuscular mycorrhizal fungi. Plant Soil 1998, 198, 97-107. [CrossRef]

43. Rilling, M.C.; Wright, S.F.; REvine, V.T. The role of arbuscular mycorrhizal fungi and glomalin in soil aggregation: Comparing effects of five plant species. Plant Soil 2002, 238, 325-333. [CrossRef]

44. Wang, S.; Wu, Q.S.; He, X.H. Exogenous easily extractable glomalin-related soil protein promotes soil aggregation, relevant soil enzyme activities and plant growth in trifoliate orange. Plant Soil Environ. 2015, 61, 66-71. [CrossRef]

45. Gao, W.Q.; Wang, P.; Wu, Q.S. Functions and application of glomalin-related soil proteins: A review. Sains Malays. 2019, 48, 111-119. [CrossRef]

46. Liu, H.; Wang, X.; Liang, C.; Ai, Z.; Wu, Y.; Xu, H.; Xue, S.; Liu, G. Glomalin-related soil protein affects soil aggregation and recovery of soil nutrient following natural revegetation on the Loess Plateau. Geoderma 2020, 357, 113921. [CrossRef]

47. Chi, G.G.; Srivastava, A.K.; Wu, Q.S. Exogenous easily extractable glomalin-related soil protein improves drought tolerance of trifoliate orange. Arch. Agron. Soil Sci. 2018, 64, 1341-1350. [CrossRef]

48. Ngosong, C.; Jarosch, M.; Raupp, J.; Neumann, E.; Ruess, L. The impact of farming practice on soil microorganisms and arbuscular mycorrhizal fungi: Crop type versus long-term mineral and organic fertilization. Appl. Soil Ecol. 2010, 46, 134-142. [CrossRef]

49. Schindler, F.V.; Mercer, E.J.; Rice, J.A. Chemical characteristics of glomalin-related soil protein (GRSP) extracted from soils of varying organic matter content. Soil Biol. Biochem. 2007, 39, 320-329. [CrossRef]

50. García-González, I.; Quemada, M.; Gabriel, J.L.; Hontoria, C. Arbuscular mycorrhizal fungal activity responses to winter cover crops in a sunflower and maize cropping system. Appl. Soil Ecol. 2016, 102, 10-18. [CrossRef]

51. Zhang, X.; Wu, X.; Zhang, S.; Xing, Y.; Wang, R.; Liang, W. Organic amendment effects on aggregate-associated organic C, microbial biomass $C$ and glomalin in agricultural soils. Catena 2014, 123, 188-194. [CrossRef]

52. Liu, A.; Ma, B.L.; Bomke, A.A. Effects of cover crops on soil aggregate stability, total organic carbon, and polysaccharides. Soil Sci. Soc. Am. J. 2005, 69, 2041-2048. [CrossRef]

53. Blanco-Canqui, H.; Shaver, T.M.; Lindquist, J.L.; Shapiro, C.A.; Elmore, R.W.; Francis, C.A.; Hergert, G.W. Cover crops and ecosystem services: Insights from studies in temperate soils. Agron. J. 2015, 107, 2449-2474. [CrossRef]

54. Carver, R.E.; Nelson, N.O.; Abel, D.S.; Roozeboom, K.; Kluitenberg, G.J.; Tomlinson, P.J.; Williams, J.R. Impact of cover crops and phosphorus fertilizer management on nutrient cycling in no-tillage corn-soybean rotation. Kans. Agric. Exp. Stn. Res. Rep. 2017, 3. [CrossRef] 
55. Hoorman, J.J.; Islam, R.; Sundermei-er, A.; Ran-dall, R. Using cover crops to convert to no-till. Crop Soil 2009, 42, 9-13.

56. De Cima, D.S.; Tein, B.; Eremeev, V.; Luik, A.; Kauer, K.; Reintam, E.; Kahu, G. Winter cover crop effects on soil structural stability and microbiological activity in organic farming. Biol. Agric. Hortic. 2016, 32, 170-181. [CrossRef]

57. Ropper, W.R. Evaluating Soil Health in North Carolina; North Carolina State University: Raleigh, NC, USA, 2018.

58. National Oceanic and Atmospheric Administration (NOAA) National Climatic Data Center (NCDC). Available online: https:// www.ncdc.noaa.gov /IPS / coop / coop.html?_page=2\&state=MS\&foreign=false\&stationID=227111\&_target3=Next $+\% 3 \mathrm{E}($ accessed on 23 March 2020).

59. Dhillon, J.; Del Corso, M.R.; Figueiredo, B.; Nambi, E.; Raun, W. Soil organic carbon, total nitrogen, and soil pH, in a long-term continuous winter wheat (Triticum aestivum L.) experiment. Commun. Soil Sci. Plant Anal. 2018, 49, 803-813. [CrossRef]

60. Nelson, D.W.; Sommers, L. Total carbon, organic carbon, and organic matter. In Methods of Soil Analysis, Part 3, Chemical Methods; Sparks, D.L., Page, A.L., Helmke, P.A., Loeppert, R.H., Nelson, D.W., Sommers, L.E., Eds.; John Wiley \& Sons: Hoboken, NJ, USA, 1996; pp. 1004-1005.

61. Reyna, D.L.; Wall, L.G. Revision of two colorimetric methods to quantify glomalin-related compounds in soils subjected to different managements. Biol. Fertil. Soils 2014, 50, 395-400. [CrossRef]

62. Kemper, W.D.; Rosenau, R.C. Aggregate stability and size distribution'. In Methods of soil analysis: Part 1 Physical and Mineralogical Methods; Klute, A., Ed.; American Society of America, Inc. Soil Science Society of America: Madison, WI, USA, 1986; Volume 9, pp. $425-442$.

63. Thomas, G.W. Soil pH and soil acidity. In Methods of Soil Analysis. Part 3; Sparks, D.L., Page, A.L., Helmke, P.A., Loeppert, R.H., Thomas, G.W., Eds.; SSSA: Madison, WI, USA, 1996; pp. 475-490.

64. Liebig, M.A.; Hendrickson, J.R.; Archer, D.W.; Schmer, M.A.; Nichols, K.A.; Tanaka, D.L. Short-term soil responses to late-seeded cover crops in a semi-arid environment. Agron. J. 2015, 107, 2011-2019. [CrossRef]

65. USDA-NRCS Soil Health Key Points. Available online: www.nrcs.usda.gov (accessed on 4 April 2020).

66. Acuña, J.C.M.; Villamil, M.B. Short-term effects of cover crops and compaction on soil properties and soybean production in Illinois. Agron. J. 2014, 106, 860-870. [CrossRef]

67. Olson, K.R.; Ebelhar, S.A.; Lang, J.M. Cover crop effects on crop yields and soil organic carbon content. Soil Sci. 2010, 175, 89-98. [CrossRef]

68. Lin, Y.; Watts, D.B.; Torbert, H.A.; Howe, J.A. Double-crop wheat and soybean yield response to poultry litter application. Crop Forage Turfgrass Manag. 2019, 5, 180082. [CrossRef]

69. Muchanga, R.A.; Hirata, T.; Araki, H. Hairy vetch and livestock compost improve soil carbon and nitrogen, and fresh-market tomato yield. HortScience 2019, 54, 1023-1030. [CrossRef]

70. Haruna, S.I. Influence of winter wheat on soil thermal properties of a Paleudalf. Int. Agrophys. 2019, 33, 389-395. [CrossRef]

71. García-González, I.; Hontoria, C.; Gabriel, J.L.; Alonso-Ayuso, M.; Quemada, M. Cover crops to mitigate soil degradation and enhance soil functionality in irrigated land. Geoderma 2018, 322, 81-88. [CrossRef]

72. Ontl, T.A.; Schulte, L.A. Soil Carbon Storage. Available online: https://www.nature.com/scitable/knowledge/library/soilcarbon-storage-84223790/ (accessed on 9 May 2020).

73. Fang, C.; Smith, P.; Moncrieff, J.B.; Smith, J.U. Similar response of labile and resistant soil organic matter pools to changes in temperature. Nature 2005, 433, 57-59. [CrossRef] [PubMed]

74. Adeli, A.; Brooks, J.P.; Read, J.J.; Shankle, M.W.; Feng, G.; Jenkins, J.N. Poultry litter and cover crop integration into no-till cotton on upland soil. Agron. J. 2019, 111, 2097-2107. [CrossRef]

75. Parker, M.A.; Nyakatawa, E.Z.; Reddy, K.C.; Reeves, D.W. Effects of taller wheat residue after stripper header harvest on wind run, irradiant energy interception, and evaporation. In Making Conservation Tillage Conventional: Building A Future on 25 Years of Research; Auburn University: Auburn, AL, USA, 2002; Volume 22, pp. 283-287.

76. Jagadamma, S.; Essington, M.E.; Xu, S.; Yin, X. Total and active soil organic carbon from long-term agricultural management practices in west Tennessee. Agric. Environ. Lett. 2019, 4, 180062. [CrossRef]

77. White, K.E.; Brennan, E.B.; Cavigelli, M.A.; Smith, R.F. Winter cover crops increase readily decomposable soil carbon, but compost drives total soil carbon during eight years of intensive, organic vegetable production in California. PLoS ONE 2020, 15, e0228677. [CrossRef]

78. Jokela, W.E.; Grabber, J.H.; Karlen, D.L.; Balser, T.C.; Palmquist, D.E. Cover crop and liquid manure effects on soil quality indicators in a corn silage system. Agron. J. 2009, 101, 727-737. [CrossRef]

79. Steele, M.K.; Coale, F.J.; Hill, R.L. Winter Annual Cover Crop Impacts on No-Till Soil Physical Properties and Organic Matter. Soil Sci. Soc. Am. J. 2012, 76, 2164-2173. [CrossRef]

80. Nichols, J.D. Relation of Organic Carbon to Soil Properties and Climate in the Southern Great Plains. Soil Sci. Soc. Am. J. 1984, 48, 1382-1384. [CrossRef]

81. Schimel, D.S.; Braswell, B.H.; Holland, E.A.; McKeown, R.; Ojima, D.S.; Painter, T.H.; Parton, W.J.; Townsend, A.R. Climatic, edaphic, and biotic controls over storage and turnover of carbon in soils. Glob. Biogeochem. Cycles 1994, 8, 279-293. [CrossRef]

82. NRCS-USDA Soil Quality Indicators. Available online: https://www.nrcs.usda.gov/wps/PA_NRCSConsumption/download? cid=stelprdb1269818\&ext=pdf (accessed on 4 August 2019).

83. Balota, E.L.; Calegari, A.; Nakatani, A.S.; Coyne, M.S. Benefits of winter cover crops and no-tillage for microbial parameters in a Brazilian Oxisol: A long-term study. Agric. Ecosyst. Environ. 2014, 197, 31-40. [CrossRef] 
84. Zhang, J.; Wang, F.; Che, R.; Wang, P.; Liu, H.; Ji, B.; Cui, X. Precipitation shapes communities of arbuscular mycorrhizal fungi in Tibetan alpine steppe. Sci. Rep. 2016, 6, 23488. [CrossRef] [PubMed]

85. Lekberg, Y.; Koide, R.T. Effect of soil moisture and temperature during fallow on survival of contrasting isolates of arbuscular mycorrhizal fungi. Botany 2008, 86, 1117-1124. [CrossRef]

86. Daniels, B.A.; Menge, J.I. Hyperparasitization of vesicular-arbuscular mycorrhizal fungi. Phytopathology 1980, 70, 584-588. [CrossRef]

87. Bai, C.; He, X.; Tang, H.; Shan, B.; Zhao, L. Spatial distribution of arbuscular mycorrhizal fungi, glomalin and soil enzymes under the canopy of Astragalus adsurgens Pall. in the Mu Us sandland, China. Soil Biol. Biochem. 2009, 41, 941-947. [CrossRef]

88. Bedini, S.; Avio, L.; Sbrana, C.; Turrini, A.; Migliorini, P.; Vazzana, C.; Giovannetti, M. Mycorrhizal activity and diversity in a long-term organic Mediterranean agroecosystem. Biol. Fertil. Soils 2013, 49, 781-790. [CrossRef]

89. Bedini, S.; Avio, L.; Argese, E.; Giovannetti, M. Effects of long-term land use on arbuscular mycorrhizal fungi and glomalin-related soil protein. Agric. Ecosyst. Environ. 2007, 120, 463-466. [CrossRef]

90. Olsson, P.A.; Thingstrup, I.; Jakobsen, I.; Bååth, E. Estimation of the biomass of arbuscular mycorrhizal fungi in a linseed field. Soil Biol. Biochem. 1999, 31, 1879-1887. [CrossRef]

91. Hetrick, S.; Ketterings, Q.; Czymmek, K.; Sadeghpour, A.; Langner, A.; O’Neil, K.; Gabriel, A. Improving Aggregate Stability, Agronomy Fact Sheet Series. Available online: http://nmsp.cals.cornell.edu (accessed on 2 April 2020).

92. Song, K.; Zheng, X.; Lv, W.; Qin, Q.; Sun, L.; Zhang, H.; Xue, Y. Effects of tillage and straw return on water-stable aggregates, carbon stabilization and crop yield in an estuarine alluvial soil. Sci. Rep. 2019, 9, 4586. [CrossRef]

93. Rorick, J.D.; Kladivko, E.J. Cereal rye cover crop effects on soil carbon and physical properties in southeastern Indiana. J. Soil Water Conserv. 2017, 72, 260-265. [CrossRef]

94. Boyle, M.; Frankenberger, W.T.; Stolzy, L.H. The influence of organic matter on soil aggregation and water infiltration. J. Prod. Agric. 1989, 2, 290-299. [CrossRef]

95. USDA-NRCS Soil quality indicators: Aggregate Stability. Soil Qual. Indic. 1996, 192, 1836-1841. [CrossRef]

96. Herath, H.M.S.K.; Camps-Arbestain, M.; Hedley, M. Effect of biochar on soil physical properties in two contrasting soils: An Alfisol and an Andisol. Geoderma 2013, 209-210, 188-197. [CrossRef]

97. Ramírez, P.B.; Fuentes-Alburquenque, S.; Díez, B.; Vargas, I.; Bonilla, C.A. Soil microbial community responses to labile organic carbon fractions in relation to soil type and land use along a climate gradient. Soil Biol. Biochem. 2020, 141, 107692. [CrossRef]

98. Sullivan, P. Overview of Cover Crops And Green Manures. Available online: https://cpb-us-e1.wpmucdn.com/blogs.cornell. edu/dist/e/4211/files/2014/04/Overview-of-Cover-Crops-and-Green-Manures-19wvmad.pdf (accessed on 6 January 2021).

99. USDA-NRCS Legumes and Soil Quality. Available online: www.mes.umn.edu (accessed on 6 April 2020).

100. Freitas, M.E.; De Souza, L.C.F.; Salton, J.C.; Serra, A.P.; Mauad, M.; Cortez, J.W.; Marchetti, M.E. Crop rotation affects soybean performance in no-tillage system under optimal and dry cropping seasons. Aust. J. Crop Sci. 2016, 10, 353-361. [CrossRef]

101. Ayolagha, G.A.; Peter, K.D. Effect of remediation on growth parameters, grain and dry matter yield of soybean (Glycine max) in crude oil polluted soils in ogoni land, South Eastern Nigeria. Asian J. Crop Sci. 2012, 4, 113-121. [CrossRef] 